\title{
Nutritional Status and Infectious Disease of Undernourished Children under five in Desa Cipacing, Jatinangor Subdistrict, West Java, from April to December 2012
}

\author{
Palomina Caesarea Nurhasanah, ${ }^{1}$ Dewi Marhaeni Diah Herawati, ${ }^{2}$ Resnaldi ${ }^{3}$ \\ ${ }^{1}$ Faculty of Medicine Universitas Padjadjaran, ${ }^{2}$ Department of Medical Nutrition Faculty of \\ Medicine Universitas Padjadjaran, ${ }^{3}$ Department of Nuclear Medicine, Faculty of Medicine \\ Universitas Padjadjaran/Dr. Hasan Sadikin General Hospital Bandung
}

\section{Abstract}

Background: Undernutrition frequently occurs in children under five. If not treated, it will cause acute health effects and affect on cognitive development, social, physical work capacity and productivity. Undernutrition can be accompanied by the presence of infectious disease that can worsen the children's nutritional status. This study aimed to describe the nutritional status and infectious disease of undernutrition children under five in Jatinangor Subdistrict.

Methods: A qualitative study was carried out to 7 parents and undernourished children under five, in Desa Cipacing, Jatinangor. It was conducted from April to December 2012. The inclusion criterias were undernourished children under five with a history of infectious disease in the previous year, and the parents were willing to participate in this study. Exclusion criteria were parents and/or the children who were not at home when the collection of the data was conducted.. Data collection was conducted using measurement of nutritional status, in depth interview and environmental observation. The data were presented in tables, figures and narration.

Results: Three subjects with undernutrition (-3SD to -2SD) and four subjects with severe undernutrition (<3SD). Factors affecting poor nutritional status were weight loss, no significant weight gain, diet and eating habit, and onset of disease. Commonly occurred infectious diseases were common cold, diarrhea, fever and cough. Some factors affecting infectious diseases were family member transmission, immunization, and treatment behavior.

Conclusions: Poor nutritional status and infectious diseases contribute to undernutrition in children under five. [AMJ.2015;2(3):339-45]

Keywords: Children under five, infectious disease, nutritional status, undernutrition

\section{Introduction}

The Millennium Development Goals (MDGs) is an objective measure used globally to measure human development and poverty reduction. One of the indicators of MDGs is achieved through lowering the prevalence of children with undernutrition and severe undernutrition. Undernutrition is one type of malnutrition that frequently occurs in infants. ${ }^{1}$

Undernutrition and malnutrition itself can be determined by assessment of nutritional status using anthropometric parameters and weightfor-age, height-fo-age, or weightfor-height indices. Undernutrition can cause several acute effects on health and long-term effects on cognitive and social development, physical work capacity and productivity if not treated.

Infectious diseases and malnutrition are major causes of mortality and morbidity in children in the developing country.,3 Based on a study, undernutrition may cause infectious disease because children have a low immune system so they are vulnerable to the disease. ${ }^{4}$ Infectious diseases which frequently arise are diarrhea, helminthes

Correspondence: Palomina Caesarea Nurhasanah, Faculty of Medicine, Universitas Padjadjaran, Jalan Raya BandungSumedang Km.21, Jatinangor, Sumedang, Indonesia, Phone: +6281321081108 Email: palominacnh@gmail.com 


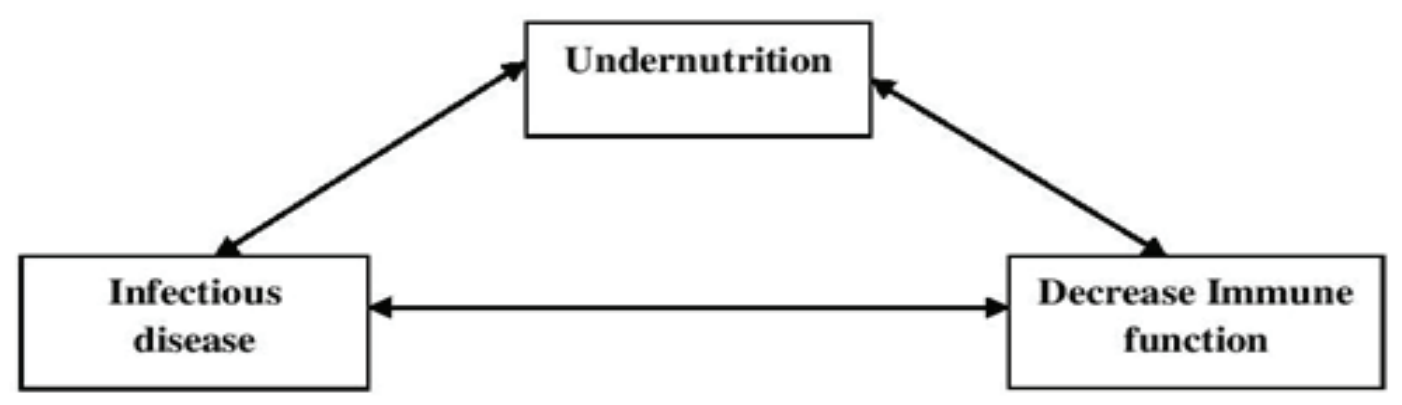

Figure 1 Undernutrition-infectious Disease Cycle

infections, bronchopneumonia, and many more. ${ }^{4}$ Undernutrition, infectious diseases and immune system form a simple cycle. If a person with normal nutritional status got an infectious disease but the infection is not treated, consequently, the disease will lower a person's nutritional status which will have an impact on the immune function. ${ }^{5,6}$ Undernutrition is a predisposing factor to infection because it can lower the body's ability to invade the pathogen. ${ }^{3}$ Furthermore, infectious diseases can also cause undernutrition and make a cycle. $^{2}$

Undernutrition-infectious disease cycle occurs when undernutrition increases the susceptibility to infectious diseases that can result in decreased food intake. ${ }^{3,6}$

Infectious diseases mediate the undernutrition by reducing food intake, decreasing absorption of nutrient, increasing nutritional needs and also relieving endogen nutrients. ${ }^{3,6}$ Infectious diseases also increase basal metabolic rate by increasing the body temperature therefore increasing the nutrient needs for metabolism. ${ }^{3}$

According to data from West Java's Health Profile, the incidence of undernutrition and severe undernutrition in Kabupaten

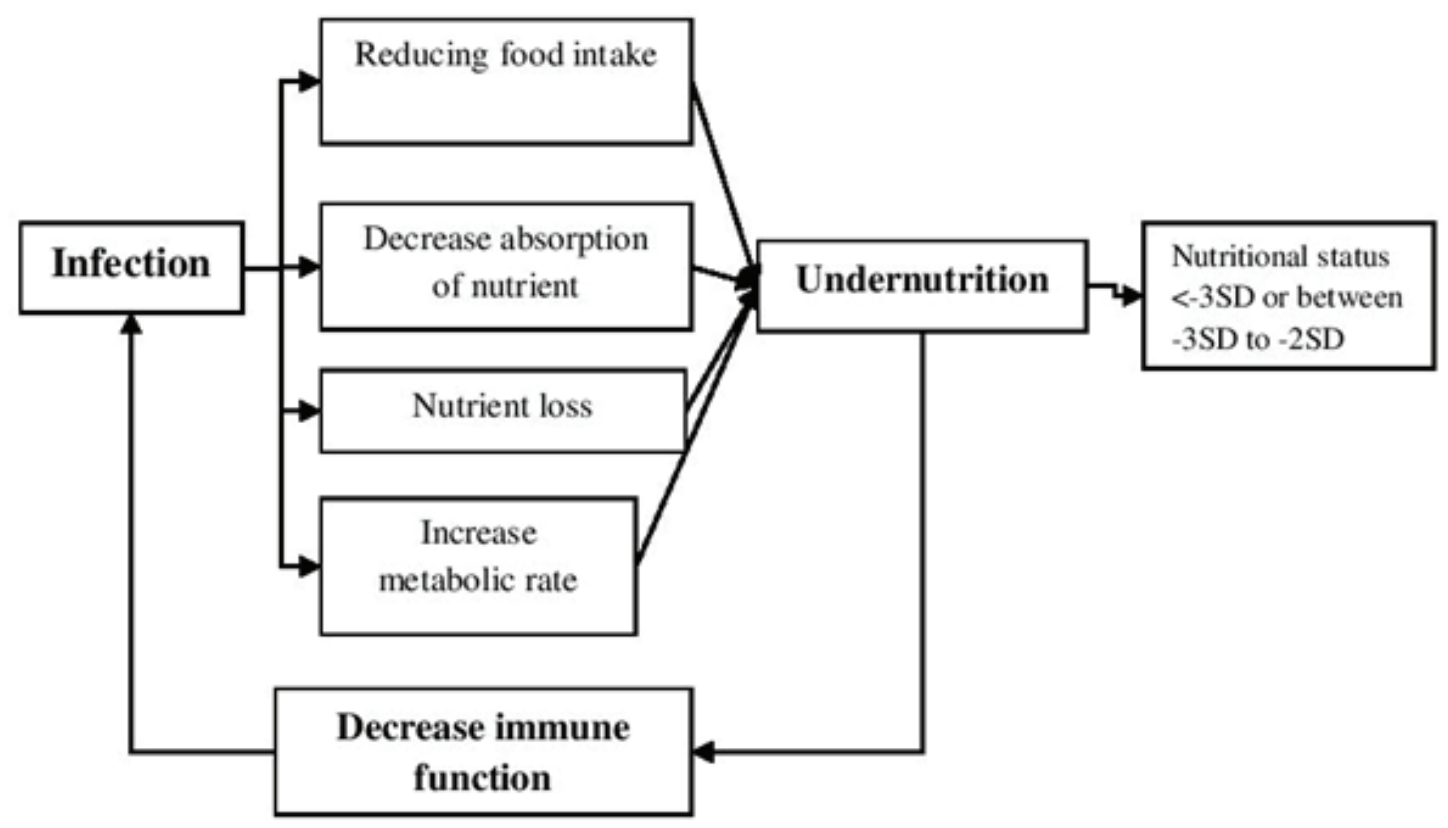

Figure 2 Relation between Infection and Undernutrition 
Sumedang (13.49\%) exceeded the incidence of West Java $(12.28 \%) .^{7}$ Based on data in Jatinangor 2011, Desa Cipacing, Sumedang has the greatest incidence of undernutrition and severe undernutrition. This study aimed to describe the nutritional status and infectious disease of undernourished children under five in Desa Cipacing.

\section{Methods}

A qualitative study ${ }^{8}$ was carried out to 7 parents who had undernourished children under five in Desa Cipacing, Jatinangor. The study was conducted from April to December 2012.

The study used the purposive sampling technique. ${ }^{8}$ The inclusion criteria were undernourished children under five. Those children have a history of infectious disease in the previous year. Their parents were willing to participate in this study. The exclusion criteria were parents and/or children who were not at home when the collecting of data was performed.

This study used several methods to collect data. The nutritional status of children were determined by measuring the weight, height, and age. The nutritional status was obtained by using weight-for-age index and the Ministry of Health's standard. An in-depth- interview was carried out to identify the presence or the experience of infectious disease. Observation of the environment was also conducted to identify the eating habit of the children

After collecting data, the initial stage for data analysis was the univariable analysis presented in tables and narrative text about the nutritional status and infectious disease of children under five. Furthermore, after interview records were transcribed, the qualitative data analysis was performed by summarizing, coding and categorizing the obtained data. The last step was making conclusions. ${ }^{8}$

\section{Results}

The nutritional status and infectious disease of undernourished children under five in Table 1 shows the result of anthropometric measurement and semi-structural interviews from seven respondents. Seven subjects included in the study had body weight under the red line using the growth chart in Kartu Menuju Sehat (KMS).

Factors which affected the nutritional status of undernourished children under five were weight development, eating habit and diet, and also onset of disease. These factors were informed by the subject's parents during the interview process. All subjects; parents acknowledged that there were weight loss from weight measurement in August by MHC up to weight measurement in October. In addition, to weight loss, no specific weight gain was also considered as the cause of children had under nutritional status. There was also subjects who experienced weight loss and no weight gain.

Problems of eating habits in these subjects was another condition that made them in undernourishedl status. Thisproblem of eating habits could be in terms of quantity, quality, or type of foods. For example, one of the subjects had difficulty in eating rice because the subject is scared to it. Decreased appetite was also the cause of these subjects who would not eat. Based on the interviews, all subjects ate twice to three times a day. The types of meals given to the subjects were rice, vegetables, meatballs, tempeh, tofu, instant noodles and fruits. Instant porridge purchased in a mini market was given to the subject who cannot

Table 1 Characteristic of Undernourished Children Under Five

\begin{tabular}{ccccc}
\hline Sample & Age(month) & Weight (KG) & \multicolumn{2}{c}{ Nutritional Status } \\
\hline R1 & 13 & 6.7 & -3 SD sd -2SD & Undernutrition \\
R2 & 27 & 8 & $<-3 S D$ & Severe Undernutrition \\
R3 & 30 & 10 & -3 SD sd -2SD & Undernutrition \\
R4 & 48 & 10 & $<-3 S D$ & Severe Undernutrition \\
R5 & 29 & 8.5 & $<-3 S D$ & Severe Undernutrition \\
R6 & 33 & 9 & $<-3 S D$ & Severe Undernutrition \\
R7 & 28 & 10 & $-3 S D ~ s d ~-2 S D$ & Undernutrition \\
\hline
\end{tabular}




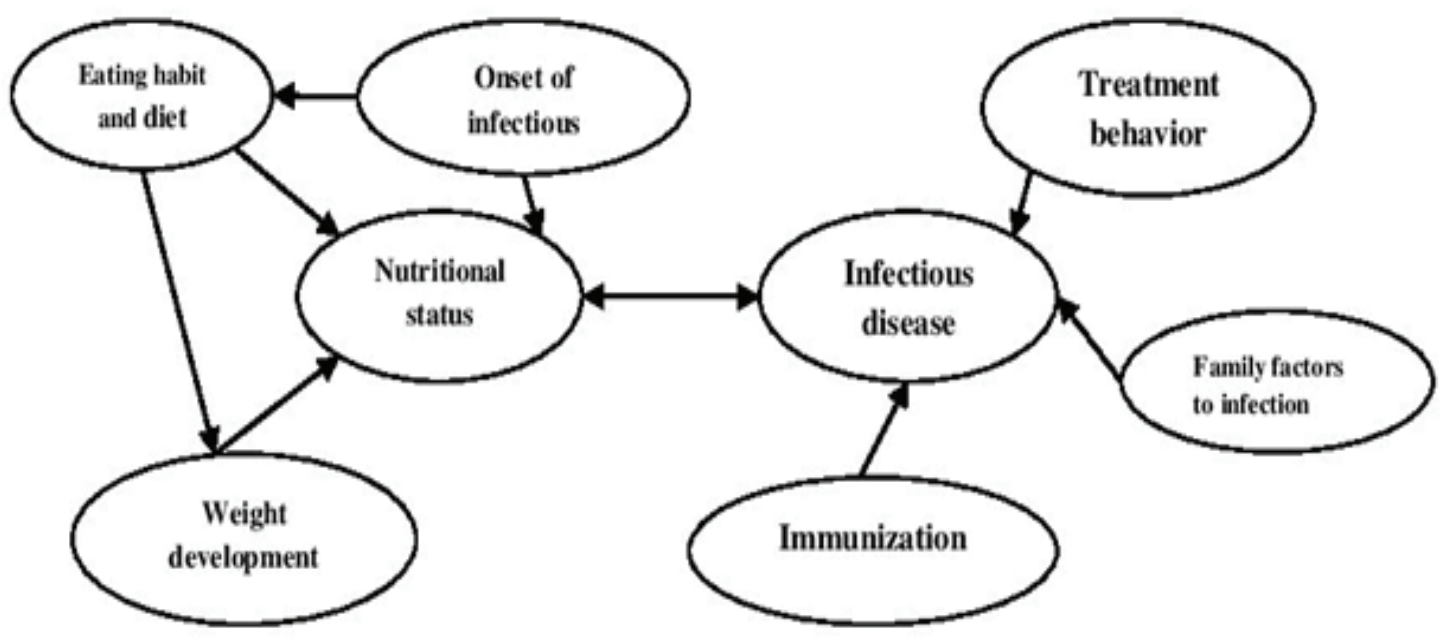

Figure 3 Mapping Concept

eat rice. In addition, most of the subjects also ate snacks bought in shops or street vendors like biscuits, dodol, cireng, chocolate cake and chocolate.

Infectious diseases having arisen during children development was also one of the reasons the subject had under nutritional status. Moreover, in the previous years, each child had several symptoms or diseases. Based on interviews, 8 children had common cold, 6 children had diarrhea, 4 children had fever, 3 children had cough and 1 child had other symptom.

Almost all study subjects had common cold in the previous year and some of the subjects were interspersed with cough and

The UNICEF conceptual framework, which the nutrition community has been using for programming for the past 25 years, identifies three levels of causes of undernutrition.

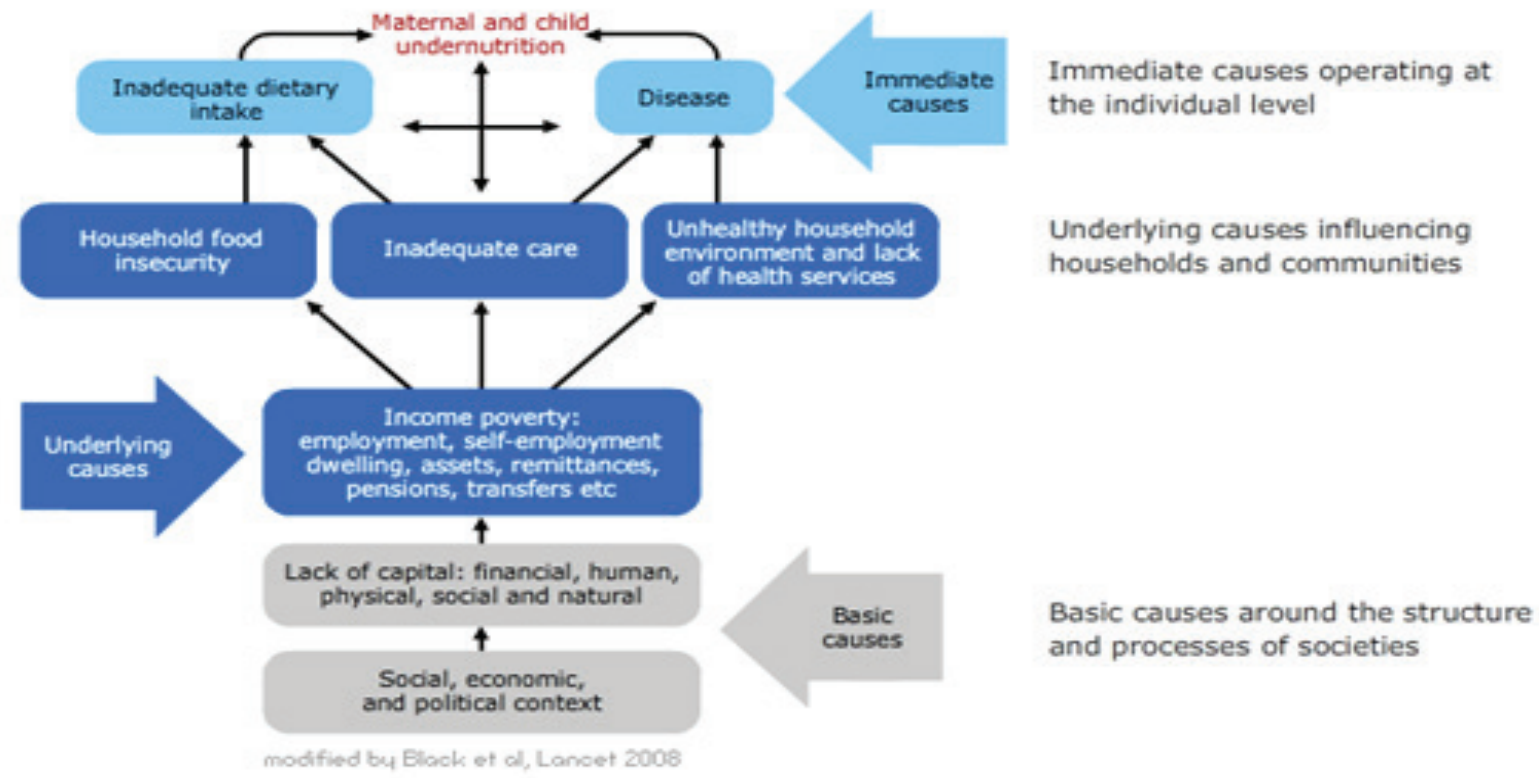

Figure 4 UNICEF Conceptual frameworks, adapted from UNICEF ${ }^{12}$ 
fever. Diarrhea was also a common disease in the subject and one of the subjects had a helminthes infection.

Some factors that affected infectious disease were family members exposed to infection, immunization, and treatment behavior. If there is one family member infected, she/ he has the potential to spread the infection to other family members. It could be seen by looking at the subjects' parents condition when the interview and direct observations were conducted.

Basic immunizations were given after birth until the age of nine months to gain immunity so that the subjects were not susceptible to diseases. Six of the seven subjects already got the full basic immunizations while only one who did not get the full basic immunizations.

Treatment behavior in this study was in the form of self medication by buying over the counter (OTC) drugs in the market. There were six parents who seek treatment for their sick children, and only one who did not seek treatment. Some of them also went to the primary health care (PHC) to cure the disease.

Based on this study, the mapping concept about nutritional status and infectious disease was obtained.

\section{Discussions}

Undernutrition is one of malnutrition caused by macronutrient or micronutrient deficiencies. ${ }^{9}$ Malnutrition can be assessed by nutritional status using weight and height measurement. ${ }^{10}$ In this study, nutritional status was according to the standard deviation of weight-for-age index and compared with theMinistry of Health's referral.

Unlike the height-for-age described past nutritional status, the weight-for-age index was used to describe present nutritional status. ${ }^{10}$ Referring to that, children's weight development influenced the determination of nutritional status. The other indices such as height-for-age or weight-for-height were not used because after compared with the referral, it led to different result (the undernourished children showed normal nutritional status while using these indices).

Weight-for-age index used to assess nutritional status was affected by current body weight measurement. In this study, both weight loss or no specific weight gained could be influenced by emerging infectious disease, history of low birth weight or the food intake. Most of the children also ate snack bought at street vendors. The nutrient content of the snacks were not known so the children likely did not get the adequate nutrition. This eating habit could affect the nutritional status. According to Masithah et al. ${ }^{11}$, a good and adequate quality diet influenced the nutritional status.

The United Nations Children's Fund (UNICEF) established a conceptual framework about factors causing malnutrition affect in the individual household and community. The household food insecurity and inadequate care are one of the causes of malnutrition. The main causes that affect undernutrition in individuals were inadequate dietary intake and disease. ${ }^{12}$ Similar to the UNICEF's concept, in this study, factors affecting the undernutritional status were infectious disease, weight loss, no specific weight gain influenced by diet and eating habit.

Overall, these children under five had undernutrition and severe undernutrition status according to the Ministry of Health reference with the various factors that underlie the undernutrition.

Undernutrition and infectious disease influenced each other. Undernutrition can decrease the immunity system so the person is susceptible to the infectious disease and vice versa. Infectious diseases which occurred in these children within the previous year were diarrhea andrespiratory infections such as common cold with cough and fever, and also helminthes infections. These diseases did not show a difference when compared to the data of West Java's Health Profile of infectious disease. ${ }^{7}$

Clinically, common cold or acute nasopharyngitis was one of acute upper respiratory tract infection (URTI) caused by rhinovirus. Cough was one of the body's reflexes to remove foreign objects by removed air from the lungs. ${ }^{13}$ Fever was a disease that cause an increase in body temperature because of increased in hypothalamic caused by pyrogen. An infectious disease could cause symptoms such as decreased appetite resulting in decreasing of food intake and disrupting nutrient absorption. ${ }^{3}$ Chronic infectious disease without treatment could influence children's condition thus cause undernutrition. ${ }^{3}$

Helminthes infection in children could affect their nutritional status. Intestinal helminthes such as Ascaris lumbricoides, Trichuris trichiura, and hookworm were the most common causes. ${ }^{14}$ Helminthes infection can alter children's nutritional status by absorbing their blood so it can cause lost of 
iron and protein. ${ }^{14}$ Helminthes infection also increased nutrient malabsorption, lost of appetite and decreased intake of nutrient. ${ }^{14}$ These related to the findings in this study that the children became undernourished when exposed to helminthes infection.

Furthermore,diarrheahadinterrelationship with undernutrition. ${ }^{15}$ Diarrhea as one of the most common disease reported in this study is a disease that could cause weight loss and undernutrition. The function of the body to absorb nutrient was decreasing and also there was fluid loss due to dehydration. These were the effect of diarrhea that could lead to undernutrition in children under five. ${ }^{15}$ Diarrhea often occurred in children leads to decrease of body weight or no weight gain thus impacting the nutritional status. Some parents thought that diarrhea in children under five was a common problem so that they did not give treatment to their children and eventually, could worsen the children's condition.

The spread of infectious disease was affected by the family condition and situation. ${ }^{16}$ If one of the family members was affected by the disease, other family members were at risk being infected. ${ }^{16}$ In this study, when mother got common cold, so did her child. It was caused by the mother who spent more time with her child than other family members. This condition made mother easily transmitted the disease to the children due to spread of infection in family. ${ }^{16}$

Immunization is an administration of vaccine in order to increase the immunity system. Basic immunization such as hepatitis $\mathrm{B}$ or measles were given after birth until the age of nine months. One of the children did not get full basic immunization because of low birth weight. In this study, children under five who got incomplete immunization turned out had more frequent infection (cold, fever, and diarrhea) when compared to children with full basic immunization.

Self medication was one of behavior treatment often done by the parents. Parents tended to give OTC drug to reduce the symptoms and waited until the child healed itself because they thought that the diseases were common in children. Treatment through PHC will be conducted by the parents if the disease has not been cured. Infectious disease should be treated immediately because if not treated, it could affect their nutritional status. ${ }^{5}$

The limitations of this study were identification of health status during pregnancy, gestation age, birth weight and comparison with normal children were not carried out.

It can be concluded that there were several factors contributed in undernourished children under five. Those were eating habit, weight development, onset of infection, immunization, treatment and disease transmission by family members.

The infectious disease occurred were diarrhea, helminth infection and upper respiratory infection (cold and cough). The study in the near future should conduct deeper interviews to obtain more information about the phenomenon in those areas.

\section{References}

1. Kusumawardhani N, Martianto D. Kaitan antara prevalensi gizi buruk dengan PDRB per kapita dan tingkatkemiskinan serta estimasi kerugian ekonomi akibat gizi buruk pada balita di berbagai kabupaten kota di pulau Jawa dan Bali. Jurnal Gizi dan Pangan. 2011;6(1):100-8.

2. Ambrus JL Sr, Ambrus JL Jr. Nutrition and infectious disease in developing countries and problems of acquired immunodeficiency syndrome. Exp Biol Med (Maywood). 2004;229(6):464-72.

3. Calder PC, Jackson AA. Undernutrition, infection, and immune function. Nutr Res Rev. 2000;13(1):32-7.

4. Islamiyati, Sadiman, Katharina K. Hubungan penyakit infeksi dengan gizi buruk pada balita di kecamatan metro barat tahun 2008. Jurnal Kesehatan Metro Sai Wawai. 2009;2(1):32-6.

5. Nelson KE. Epidemiology of infectious diseases: general principles. In: Nelson $\mathrm{KE}$, Williams CM. Infectious disease epidemiology: theory and practice. 2 nd ed. Sudbury: Jones and Bartlett; 2007. p. 26-8.

6. Schaible UE, Kaufmann SH. Malnutrition and infection: complex mechanisms and global impacts. PLoS Med. 2007;4(5):e115.

7. Dinas Kesehatan. Lampiran tabel profil kesehatan Provinsi Jawa Barat tahun 2007. Bandung: Dinas Kesehatan Provinsi Jawa Barat.2008.

8. Curry LA, Nembhard IM, Bradley EH. Qualitative and mixed method provide unique contributions to outcomes research. Circulation. 2009;119(10):1442-52.

9. Fauci AS, Kasper DL, Longo DL, Braunwald E, Hauser SL, Jameson JL, et al., editors. Malnutrition and nutritional assesment. $17^{\text {th }}$ ed. New York: McGraw-Hill companies; 2008.

10. Supariasa IDN, Bakri B, Fajar I. Penilaian 
status gizi. Jakarta: EGC; 2001.

11. Masithah T, Soekirman, Martianto D. Child care practices associated with child nutritional status in rural Mulya Harja, Bogor. Media Gizi \& Keluarga. 2005;29(2):29-39.

12. UNICEF. UNICEF Conceptual frameworks. New York: United Nations Children'sFund;2008 [Cited 2013 February 01]; Available from: http://www.unicef. org/nutrition/training/2.5/4.html.

13. Madison JM, Irwin RS. Cough: a worldwide problem. Otolaryngol Clin North Am. 2010;43(1):1-13.

14. WHO. Soil-transmitted helminth infections.
Geneva: World Health Organization;2012. [Cited 2013 February 01]. Available from: http://www.who.int/mediacentre/ factsheets/fs366/en.

15. Palupi A, Hadi H, Soenarto SS. Status Gizi dan hubungannya dengan kejadian diare pada anak diare akut di ruang rawat inap RSUP Dr. Sardjito Yogyakarta. Jurnal Gizi Klinik Indonesia. 2009;6(1):1-7.

16. McWhinney IR, Freeman T. The family in health and disease. In: McWhinney IR, Freeman T. Textbook of family medicine. 3rded. New York: Oxford University Press; 2009. p. 217-28. 